\title{
Isolation, molecular characterization and preliminary screening for probiotic properties of lactobacillus fermentum from indigenous dahi
}

\author{
Wajiha Farid ${ }^{1, *}$, Tariq Masud ${ }^{1}$, and Asma Sohail ${ }^{1}$ \\ ${ }^{1}$ Institute of Food and Nutritional Science, Pir Mehr Ali Shah, Arid Agriculture University \\ Rawalpindi, Pakistan.
}

\begin{abstract}
Indigenous dahi is an analogue to fermented milk product of Pakistan produce by uncharacterized strains of LAB. It hides lots of health beneficial properties and unexplored micro-flora. On microbial examination of indigenous dahi, it was found that $L$. fermentum was most dominant spp. (22 isolates) of LAB in it. Upon safety assessment eleven showed negative hemolytic and gelatinase activity. All these eleven strains were molecularly characterized through PCR by using universal primers ( $9 \mathrm{~F}$ and $1510 \mathrm{R}$ ). Obtained sequences were submitted to Gene data base of NCBI under accession numbers KX944639-42, KX957930-33 and KY069971-73. Furthermore these strains were screened on the basis of acid and bile tolerance and antimicrobial activity. KX957931, KX957932 and KY069973 were selected for further studies of functional attributes.
\end{abstract}

\section{Introduction}

"Probiotics are the live microorganisms which when administered in an adequate amount confer health benefits to the host" [1]. For strains to be probiotic must passed through safety parameters, after that their tolerance against acidic conditions of stomach and bile conditions of intestine matters a lot. Antimicrobial potential of probiotic is mostly the main criteria for the selection strain.

Indigenous dahi from Pakistan hides a lot of probiotic strains but mostly remain unexplored. It is fermented milk product produce from wild/ non cultured multiple strains of LAB (Lactic acid bacteria). Exploration of new environments and populations for distinct strains of a probiotic species provide an opportunity for better and safest probiotic strains.

There have been a number of reports for isolating the probiotic lactobacilli from human gastrointestinal and urinogenital tract [2-3]. But the isolation from locally fermented milk product is not been yet reported ${ }^{1}$ from Pakistan [4]. We aimed to isolate, identify and characterize probiotic lactobacillus fermentum from fermented milk (dahi). The isolates were characterized by tolerance to low $\mathrm{pH}$, resistance to bile, antimicrobial activity and

\footnotetext{
*Corresponding author wajihafareed@yahoo.com
} 
molecular level characterization including sequence analysis of screened strains by utilizing 16S rRNA gene amplification.

\section{Materials and methods}

\subsection{Sample collection and isolation of $L$. fermentum}

This study was conducted at Department of Food Technology, University of Arid Agriculture Rawalpindi, Pakistan. One hundred and five Samples of indigenous dahi were randomly collected to explore the potential of this area regarding probiotics. Isolation of $L$. fermentum was done by following streak plate method. Samples were streaked separately on MRS (Mann Regosa Sharpe,Oxoid, Basingstoke, UK) plates supplemented with 2\% mannitol and Lactose and $0.7 \%$ bile salts (Oxoid) and incubated anaerobically for $24-48 \mathrm{hrs}$ at $37^{\circ} \mathrm{C}$.

\subsection{Phenotypic characterization of $L$. fermentum isolates}

Gram staining, catalase and carbohydrate fermentation tests (API) were performed for preliminary identification by following the methods described in Bergey's manual [5].

\subsection{Safety Assessment}

\subsubsection{Haemolytic activity}

Haemolytic activity was determined by the method described by Pisano et al.[6] in which strains were streaked on Columbia Blood (Microbiol) agar plates supplemented with 5\% defibrinated sheep blood after $48 \mathrm{~h}$ of incubation at $37^{\circ} \mathrm{C}$. The haemolytic reaction was recorded by observation of a clear zone of hydrolysis around the colonies ( $\beta$-haemolysis), a partial hydrolysis and greenish zone ( $\alpha$-haemolysis), or no reaction ( $\gamma$-haemolysis).

\subsubsection{Gelatinase activity}

Gelatinase activity of isolates were assessed by supplementing $2 \%$ gelatin to nutrient media. Inoculation of overnight grown culture was done before the media was fully solidified and incubate at $37{ }^{\circ} \mathrm{C}$ for $24 \mathrm{hrs}$. Those strains that utilizes gelatin were gelatinase positive indicated by liquefaction of media [6].

\subsection{Molecular characterization of isolates by Colony PCR}

Molecular characterization of bacterial isolates was done by colony polymerase chain reaction (PCR) using universal primers (1510R and 9F) (Table 1). DNA Template formation, PCR assay conditions and gel electrophoresis were performed by the methods described in Farid et al. [7] and Farid et al. [8]. Briefly colonies of $24 \mathrm{hr}$ grown were picked and mixed in TE buffer and was heated at $80^{\circ} \mathrm{C}$ for 15 mins. After centrifugation supernatant was used as template. Reaction mixture and conditions followed were mentioned in Table 2. 
Table 1. Sequence of universal primers $1510 \mathrm{R}$ and $9 \mathrm{~F}$ used in colony PCR

\begin{tabular}{|l|l|}
\hline \multicolumn{2}{|c|}{ Universal primers } \\
\hline $1510 \mathrm{R}$ & 5'-GGCTACCTTGTTACGA-3' \\
$9 \mathrm{~F}$ & 5'-GAGTTTGATCCTGGCTCAG-3' \\
\hline
\end{tabular}

Table 2. Amount of aliquot used and conditions followed in PCR

\begin{tabular}{|c|c|c|c|c|}
\hline Reaction mixture & Amount & \multicolumn{3}{|c|}{ Conditions } \\
\hline ;DNA template & $2 \mathrm{ul}$ & Initial denaturation & $94^{\circ} \mathrm{C}$ & 2 \\
\hline Reaction buffer & 1ul & \multicolumn{3}{|c|}{33 cycles of } \\
\hline magnesium chloride & $0.6 \mu \mathrm{l}$ & \multirow{2}{*}{$\begin{array}{l}\text { Denaturation } \\
\text { Annealing }\end{array}$} & \multirow{3}{*}{$\begin{array}{l}94^{\circ} \mathrm{C} \\
56^{\circ} \mathrm{C}\end{array}$} & \multirow{3}{*}{$\begin{array}{l}1 \mathrm{~min} \\
1 \mathrm{~min}\end{array}$} \\
\hline Primers & & & & \\
\hline Reverse & $0.5 \mathrm{ul}$ & \multirow{3}{*}{ Extension } & & \\
\hline Forward & $0.5 \mathrm{ul}$ & & \multirow[t]{2}{*}{$72^{\circ} \mathrm{C}$} & \multirow{2}{*}{$\begin{array}{l}1: 30 \\
\operatorname{mins}\end{array}$} \\
\hline Taq DNA polymerase & $0.4 \mathrm{ul}$ & & & \\
\hline dNTPs & $0.2 \mathrm{ul}$ & Final extension & $72^{\circ} \mathrm{C}$ & $20 \mathrm{mins}$ \\
\hline Water & $4.8 \mathrm{ul}$ & Hold and sotred & $4^{\circ} \mathrm{C}$ & ---------- \\
\hline
\end{tabular}

\subsubsection{Sequencing and Sequence analysis}

The amplified products of screened isolates were sent to macrogen (Korea) for sequencing in sense and antisense directions. The obtained sequences were analyzed by using BioEdit sequence alignment software and BLAST tool of National Centre for Biotechnology Information (NCBI) (http://blast.ncbi.nlm.nih.gov/Blast.cgi).

\subsection{Probiotic properties}

\subsubsection{Acid and bile tolerance of L. fermentum isolates}

Acid tolerance of bacterial isolates was conducted by the method described by Hassanzadazar, et al. [9] and Singhal, et al. [10] with some modifications. Overnight grown culture of L. fermentum in MRS broth (Oxoid, Basingstoke, UK) at $37^{\circ} \mathrm{C}$ was inoculated (1\%) to MRS broth with adjusted $\mathrm{pH}$ of 1.5 and 2 with $1 \mathrm{M} \mathrm{HCl}$ for acid tolerance and $2 \%$ bile salts (Oxoid, Basingstoke, UK) for bile tolerance test. The broths were incubated at $37^{\circ} \mathrm{C}$ for 2 and $4 \mathrm{~h}$ for acid tolerance and at same temp for $12 \mathrm{~h}$ for bile tolerance. Bacterial cell survival was determined by pouring the appropriate dilution on MRS plates and calculating $\mathrm{cfu} / \mathrm{ml}$.

\subsubsection{Antimicrobial activity}

The antagonistic effects of partially purified bacteriocins of isolated culture against indicator organisms including $E$. coli and $S$. aureus were tested by the paper disc method [11-12]. For cell free supernatant, firstly $\mathrm{pH}$ of overnight grown culture was adjust to 5.5 with $1 \mathrm{M} \mathrm{NAOH}$ than centrifugation was performed at $10,000 \mathrm{rpm}$ for $15 \mathrm{~min}$, cell free supernatant was collected and pass through 0.2 um syringe filter to remove bacterial cell.

The concentration of overnight grown culture of test organisms was adjusted according to $0.5 \mathrm{McFarland}$. Sterile filter paper discs measuring $6 \mathrm{~mm}$ diameter, thin type with an adsorbed aliquot of $25 \mathrm{ul}$ of cell free supernatant, was placed on nutrient agar plates containing a target strain and left it overnight at room temp. After that incubation was done 
for $24 \mathrm{hr}$ at $37{ }^{\circ} \mathrm{C}$ the inhibitory activity was evaluated, based on the formation of a clear zone around the paper disk.

\section{Results and discussion}

\subsection{Isolation and phenotypic characterization}

As far as isolation is concerned it was done on different culture media's to check bacterial response to specific type of media. MRS media were supplemented by $2 \%$ of Lactose and mannitol and $0.7 \%$ of bile salts. Twenty two isolates of $L$. fermentum were recovered by phenotypic characterization or identification (Table 3). Maximum number of L. fermentum was found on lactose supplemented media followed by bile salts (Table 4). Mannitol yielded least number of isolates. Lactose supports the growth thus maximum number of isolates were recovered on it.

Table 3. Phenotypic characterization of L. fermentum isolates

\begin{tabular}{|l|c|l|c|l|c|}
\hline \multicolumn{6}{|c|}{ L. fermentum } \\
\hline Morphology & Bacilli & Sucrose & + & Melibiose & + \\
\hline Gram Staining & + & Ribose & + & Mannose & + - \\
\hline Catalase & - & Xylose & - & Raffinose & + \\
\hline Mobility & - & Trehalose & $-/+$ & Rhamnose & - \\
\hline Fructose & + & Melizitose & - & Gluconate & + \\
\hline Glucose & + & $\begin{array}{l}\text { Nitrate } \\
\text { reductase }\end{array}$ & - & Amygdaline & - \\
\hline Galactose & + & $\begin{array}{l}\mathrm{CO}_{2} \\
\text { production } \\
\text { from glucose }\end{array}$ & + & Arabinose & $-/+$ \\
\hline Lactose & + & $\begin{array}{l}\text { Growth at } \\
15^{0} \mathrm{C}\end{array}$ & - & Cellobiose & + \\
\hline Sorbitol & + & $30^{0} \mathrm{C}$ & + & Esculine & - \\
\hline Maltose & + & $45^{0} \mathrm{C}$ & + & Mannitol & - \\
\hline
\end{tabular}

Table 4. Media supplementation and recovered isolates

\begin{tabular}{|l|l|}
\hline Media supplementation & No. of isolates \\
\hline Lactose & 11 \\
\hline Mannitol & 4 \\
\hline Bile salts & 7 \\
\hline
\end{tabular}

\subsection{Safety assessment}

Among twenty two isolates, eleven had showed negative response towards hemolytic and virulence related enzymes gelatinase and were further pass through molecular characterization.

\subsection{PCR and Sequencing}

In present study primers $9 \mathrm{~F}$ and $1510 \mathrm{R}$ were use for the amplification of conserved region of $16 \mathrm{~S}$ rRNA, resulted in a product of $1.5 \mathrm{~kb}(1500 \mathrm{bps})$ fragments confirming that the isolated bacteria were from genus lactobacillus. Rahayu, et al., [13], used same primers set for amplification of bacterial 16S rRNA gene and reported the PCR product of $1.5 \mathrm{kbs}$. 
Obtained sequence was first edited or chopped for the removal of primer binding sites and then aligned by using BioEdit sequence alignment software. Accession numbers (KX944639-42, KX957930-33, KY069971-73) provided by GeneBank after submission of sequences.

\subsection{Acid tolerance of $L$. fermentum isolates}

Acid tolerance of isolates at $\mathrm{pH} 1.5$ and 2 for 2 and $4 \mathrm{~h}$ has been shown in figure 1. Results indicate that only four (KX957931, KX957932, KY069972 and KY069973) strains had shown tolerance to $\mathrm{pH} 1.5$ for $4 \mathrm{~h}$ and five strains (KX944641, KX957931, KX957932, KY069972 and KY069973) tolerated the same $\mathrm{pH}$ for $2 \mathrm{~h}$ with 3.34 and $4.19 \log \mathrm{cfu} / \mathrm{ml}$ were found to be the maximum respectively. As far as $\mathrm{pH} 2$ was concerned 8 strains (L2, L3, B1, B2, B3, M1, M2 and M3) showed tolerance for 2 hrs and 6 strains (L3, B2, B3, $\mathrm{M} 1, \mathrm{M} 2$ and M3) tolerated the same $\mathrm{pH}$ for $4 \mathrm{~h}$ with 5.15 and $4.92 \log \mathrm{CFU} / \mathrm{ml}$ were found to be the maximum respectively.

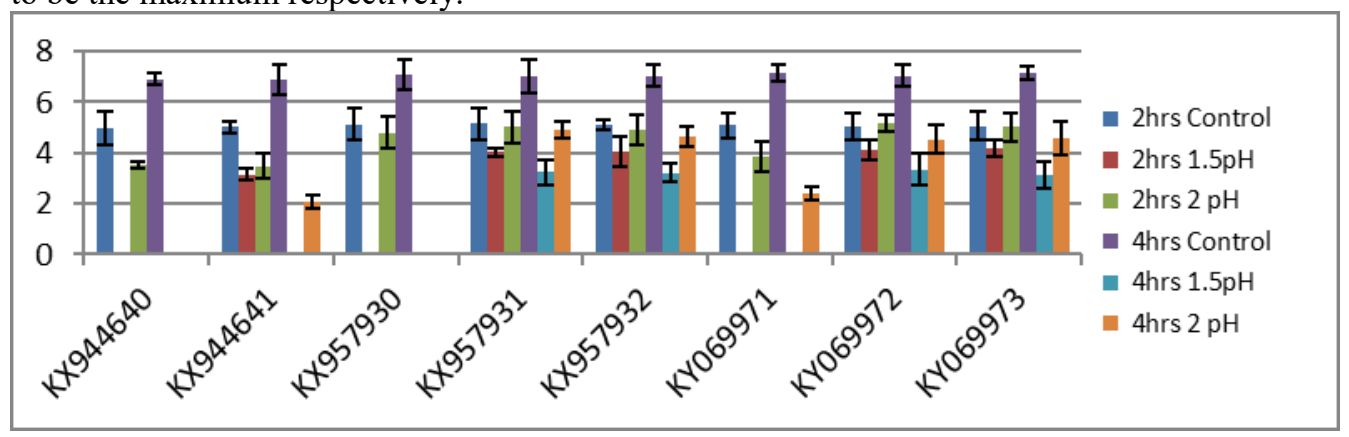

Figure 1. Comparison of different strains of L. fermentum for their acid tolerance at $\mathrm{pH} 1.5$ and 2 for 2 and 4 hrs of incubation.

\subsection{Bile tolerance of $L$. fermentum isolates}

Strains (KX944640, KX944641, KX957930, KX957931, KX957932， KY069971, KY069972 and KY069973) which showed tolerance to acidic medium of stomach was further examined for their bile tolerance represented in table 5. Out of eight three strains had shown survival under bile and alkaline conditions of intestine.

Table 5. Growth $(\log \mathrm{cfu} / \mathrm{ml})$ of selected strains under bile conditions after 4,8 and 12 hrs of incubation

\begin{tabular}{|l|c|l|l|l|l|l|}
\hline \multicolumn{7}{|c|}{ Log cfu/ml 2\% bile } \\
\hline Strains & Control & 4hrs & Control & 8hrs & Control & 12hrs \\
\hline KX944640 & $6.92 \pm 0.05$ & - & $8.25 \pm 0.25$ & - & $10.06 \pm 0.86$ & - \\
\hline KX944641 & $6.90 \pm 0.75$ & - & $8.42 \pm 0.29$ & - & $10.15 \pm 0.51$ & - \\
\hline KX957930 & $7.08 \pm 0.86$ & - & $8.54 \pm 0.54$ & - & $10.08 \pm 0.72$ & - \\
\hline KX957931 & $7.01 \pm 0.64$ & $5.025 \pm 0.25$ & $8.28 \pm 0.68$ & $4.28 \pm 0.86$ & $9.96 \pm 0.95$ & - \\
\hline KX957932 & $7.05 \pm 0.45$ & $5.34 \pm 0.68$ & $8.63 \pm 0.35$ & $4.44 \pm 0.15$ & $9.85 \pm 0.54$ & - \\
\hline KY069971 & $7.14 \pm 0.35$ & - & $8.29 \pm 0.57$ & - & $10.12 \pm 0.41$ & - \\
\hline KY069972 & $7.05 \pm 0.42$ & - & $8.65 \pm 0.95$ & - & $10.03 \pm 0.75$ & - \\
\hline KY069973 & $7.15 \pm 0.15$ & $5.52 \pm 0.95$ & $8.38 \pm 0.42$ & $4.51 \pm 0.98$ & $9.89 \pm 0.35$ & $3.59 \pm 0.95$ \\
\hline
\end{tabular}


Both acidic and alkaline bile conditions are hazardous for living things. Previously data revealed that this much low $\mathrm{pH}$ (1.5) and high concentration of bile salts affect the growth and metabolism of LAB (Lactic acid bacteria) very severely and decreases their viability [14]. But as a probiotic strain, they have to possess some resistance against them while passing through the acidic conditions of stomach and bile in intestine. Different strains of LAB showed survival against these harsh conditions of stomach [15] and intestine [6].

\subsection{Antibacterial activity of $L$. fermentum strains}

Strains KX957931, KX957932 and KY069973 were further checked for their antibacterial activity against E. coli and Staphylococcus aureus at two different values of pH 4.5 and 7. All the three strains showed considerable amount of antibacterial activity against tested organisms (figure 2). Comparatively among three strains KY069973 has shown maximum zone of inhibition against $S$. aureus and E.coli at pH 4.518 .25 and $19.75 \mathrm{~mm}$ respectively. LAB have reported previously for high antimicrobial activity, so like other LAB, $L$. fermentum also have strong potential to inhibit the growth of harmful bacteria.

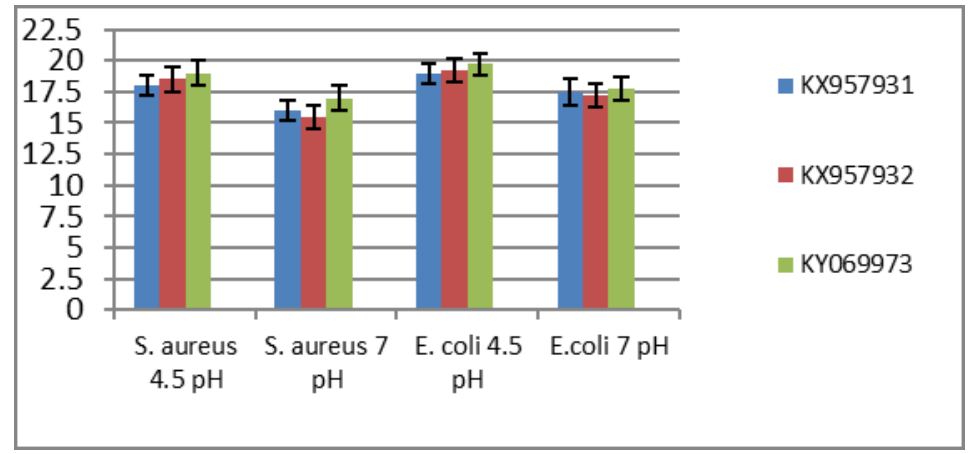

Figure 2. Antibacterial activity of selected strains of L. fermentum against $S$. aureus and E. coli at different $\mathrm{pH}$.

\section{Conclusion}

L. fermentum from indigenous dahi of Pakistan like other LAB was potential but unexplored or ignored candidate to be selected as probiotic. Due to its strong potential to resist and survive under acidic and bile conditions and high antimicrobial activity, it is potential candidate to be selected as probiotic.

\section{References}

1. C. Hill, F. Guarner, G. Reid, G. R. Gibson, D. Merenstein, B. Pot, L. Morelli, R. B. Canani, H. J. Flint, S. Salminen. Nat. Rev. Gastroenterol. Hepatol, 11, 506-514 (2014)

2. Y. F. Kazi, S. Sobia, K. Nasreen. BMC Urology, 12-22 (2012).

3. M. Nawaz, W. Juan, Z. Aiping, M. Chaofeng, W. Xiaokang, X. Jiru. African J. Microbiol. Res, 5(12), 1428-1436 (2011)

4. T. Masud, K. Sultana, Shah M. A. 4(4), 329-331 (1991)

5. R. E. Buchanan, N. E. Gibbons. Bergey's Manual of Determinative Bacteriology. $8^{\text {th }}$ ed., p.1268. (1974)

6. M. B. Pisano, V. Silvia, S, Conti, E. F. Maria, D. Maura, P. M. Maria, D. Monica, C. 
Sofia. BioMedical Res. Int, 28(6), 390-399 (2014)

7. W. Farid, T. Masud, A. Sohail, S. Naqvi, M. A. Qazalbash. 2016. Int. J. Biosciences, 9(5), 19-27 (2016).

8. W. Farid, T. Masud, A. Sohail, N. Ahmad, S. M. S. Naqvi, S. Khan, A. Ali, S. A. Khalifa, A. Hussain, A., S. Ali, M. Saghir, A. Siddeeg, M. F. Manzoor. Food Sci. Nutri, 9, 5092-5102 (2021)

9. H. Hassanzadazar, A. Ehsani, K. Mardani J. Hesari. Vet. Res. Forum, 3(3), 181-185 (2012).

10. K. Singhal, H. Joshi, B. L. Chaudhary. J. Global Pharma Technol, 2, 17-25 (2010)

11. S. Ohmomo, S. Murata, N. Katayama, S. Nitisinprasart, M. Kobayashi, T. Nakajima, M. Yajima K. Nakanishi. J. Appl. Microbiol, 88, 81-89 (2000)

12. T. H. Soomro, T. Masud. Food Sci. Technol. Res, 18, 91-98. (2012)

13. T. H. Rahayu, I. Gandjar, E. Riani, I. S. Djunaidah, A. Sjamsuridzal. Microbiol. Indonesia, 3(2), 56-60 (2009).

14. X. Liu, W. Liu, Q. Zhang, F. Tian, G. Wang, H. Zhang, W. Chen. Food Control, 3, 563-568 (2013).

15. H. K. Chan, R. P. K. Sahadeva, S. F. Leong. Int. Food Res. J, 18(4), 1515-1522 (2011). 